\title{
Effect of 3D Visualization on Students' Critical Thinking Skills and Scientific Attitude in Chemistry
}

\section{Tiwi Nur Astuti}

S.Pd., Chemistry Education Master's Programme, Graduate School, Universitas Negeri Yogyakarta, Indonesia, tiwinura.2017@student.uny.ac.id

\section{Kristian Handoyo Sugiyarto}

Prof. Dr., Department of Chemistry Education, Faculty of Mathematics and Natural Sciences, Universitas Negeri Yogyakarta, Indonesia, sugiyarto@uny.ac.id

\section{Jaslin Ikhsan}

M.App.Sc. Dr., Department of Chemistry Education, Faculty of Mathematics and Natural Sciences, Universitas Negeri Yogyakarta, Indonesia, jikhsan@uny.ac.id

The 3D visualization program paves the way for the development of virtual reality. This study produces a 3D visualization program in virtual reality to increase high school students' critical thinking skills and scientific attitude. The Research and Development (R\&D) method was based on the ADDIE model analysis, design, develop, implement, and evaluate with quasi experimental - posttest design. The data of students' scientific attitude was collected through questionnaire adapted from several books and jounals, and those of the students' critical thinking skills was collected through chemical bonding test. A total of 96 grade 10th students were cluster randomly selected from senior high school in Gunungkidul Regency, Yogyakarta, Indonesia. The samples were set into three different classes, namely Class CG using a wet laboratory, Class EG-1 using a virtual reality laboratory integrated hybrid learning, and Class EG-2 using both of them. Based on the MANOVA test, it was found that students who used 3D visualization had better results in critical thinking skills and scientific attitudes.

Keywords: 3D visualization, virtual reality, hybrid learning, critical thinking skills, scientific attitude

\section{INTRODUCTION}

The new national curriculum emphasizes the importance of $21^{\text {st }}$ century skills. The $21^{\text {st }}$ century skills were known as $4 \mathrm{C}$ which include critical thinking and problem solving, communication, collaboration, creativity and innovation (Roekel, 2012). Students were required to be more active in learning so they can find concepts with direct experience

Citation: Astuti, T. N., Sugiyarto, K. H., \& Ikhsan, J. (2020). Effect of 3D Visualization on Students' Critical Thinking Skills and Scientific Attitude in Chemistry. International Journal of Instruction, 13(1), 151-164. https://doi.org/10.29333/iji.2020.13110a 
and train critical thinking to solve problems. The $21^{\text {st }}$ century skills encourage students to develop their participation in learning, encourage communication and cooperation, improve their critical thinking skills, access and analyze information communication technology, and find a concept through their creativity by developing scientific attitudes in order to solve problems (Saavedra \& Opfer, 2012; Wagner, 2008).

Critical thinking can be defined as the art of analysis and evaluating thinking with improving skills and attitudes (Paul \& Elder, 2006). Critical thinking tests can use short essays to evaluate arguments or use multiple choice questions (Bart 2010; Ennis, 1993; Ennis, 2009). The purpose of critical thinking was to test an opinion or idea, including taking into consideration or thinking based on the opinions proposed. Students must be able to interpret, analyze, evaluate, explain, and conclude the problems that exist. Teachers should get their students to apply critical thinking processes to encourage critical thinking skills (Daud \& Husin, 2004) and to use new information or manipulate existing knowledge so as to obtain reasonable responses to new situations (Lewis \& Smith, 1993; Perkins \& Murphy, 2006).

Scientific attitude is the ability to react consistently, rationally, and objectively in a certain way to deal with a problem that is reflected through one's behavior (Olasehinde \& Olatoye, 2014; Jancirani et al., 2012). Activities of students in carrying out a scientific research to sharpen their scientific knowledge and skills is an action that reflects a scientific attitude. Teachers' role in teaching and learning process also influences the motivation to be scientific in students (Senler, 2016). When the teacher gives examples of scientific attitudes in learning activities, it will lead to a desire in students to participate in doing scientific attitudes in their daily lives. Scientific attitude includes attitude of curiosity, open-mindedness, attitude of discovery, open attitude, honesty, critical thinking, objective, responsibility, cooperation, and firm stance is someone who has a scientific attitude (Pitafi \& Farooq, 2012; Astutik \& Praharani, 2018).

Virtual learning is a new generation of types of learning using computers (Bakar et al., 2013). Virtual package represents a comprehensive application of computer modeling, simulation technologies, and analysis. As technology develops, a lot of research is done by utilizing $3 \mathrm{D}$ visualization models in a software to provide real-world representation. The $3 \mathrm{D}$ visualization makes it possible for people to see things that are unlikely to be seen in the real world, and observe things that are not possible in the real world (Wu et al., 2010). Virtual reality (VR) is a new 3D interpretation environment built on the basis of $3 \mathrm{D}$ visualization. Visualization technologies have intrinsic properties and activate cognitive tools that help students to learn and even build content with what they studied or understood on their subject contents (Sural, 2018).

Virtual reality was very useful in helping students understand how to design research experiments because using a computer system can provide a good simulation of what should happen in the real world and help them to collect data, analyze, and train students to understand how a scientist can explain what they are researching. The conventional teaching in chemistry lab processes is the learners to the use of various harmful chemical substances. So, a careful preparation for the experiments and substances for the 
apparatus and substances. Experiments carried out conventionally in schools cannot be done individually because students are high cost of the materials (Allwright, 1991). Therefore, it is necessary to conduct research to determine the effectiveness of virtual laboratories as a substitute for traditional laboratories (Hawkins \& Phelps, 2013). An interview survey carried out by the chemistry teacher in the pre-analysis stage revealed that the topic "chemical bonding" was the most difficult topic for the students.

One important aspect of $21^{\text {st }}$ century skills is critical thinking skills. These skills always encourage students to behave scientifically in all their actions. However, in chemistry subjects there are many abstract materials so that students have difficulty thinking critically in solving problems. In addition, chemistry is also closely related to practicum which requires the scientific attitude of students. In order to help students, improve their imagination in thinking critically and getting used to being scientific, we need media that can facilitate students in understanding the concept. Therefore, it is necessary to develop 3D visualization media in the form of virtual reality.

To overcome these various problems in teaching and learning of chemistry, this study, which is designed for the development of a virtual reality laboratory integrated hybrid learning. Hybrid learning is learning that combines face-to-face and online phases (Zhao $\&$ Breslow, 2013) and as long as it is linked to internet, the latter component of the class can be done anywhere (Solikhin et al., 2018). Hybrid learning can make the learning atmosphere more interesting and interactive. In addition, students can also study online outside of school hours and anywhere. The attitude of students toward hybrid learning is very positive and they are generally satisfied with their learning experience (Antonoglou, 2011). This virtual reality laboratory also offers the students to relate their learning through real situations through the use of videos, which provide more meaningful and effective chemistry lessons. An effective way of simulating is preparation for laboratory activities (Rutten et al., 2012). Therefore, the general objective of this study was to develop a virtual reality and the main purpose of this study was to examine the effect of 3D visualization on students' critical thinking skills and scientific attitude in chemistry.

\section{METHOD}

\section{Research Design}

This study used a Research and Development (R \& D) method, specifically, the ADDIE model consists of five main stages: (1) analysis; (2) design; (3) develop; (4) implement; (5) and evaluate. The product of this development was a 3D visualization program based virtual reality in a chemical bonding practicum. In the implementation phase, 3D visualization media was tested in 3 classes with a quasi-experiment design. This design appears to be the most suitable for evaluating the effects of $3 \mathrm{D}$ visualization, because it was a comparison of teaching and learning processes between the virtual reality classroom, the conventional classroom using wet laboratory, and both of them on the same topic can be performed. This experiment was followed by a quasi-experimental design where there was two experimental group (EG-1 and EG-2) and one control group (CG). The procedures involved a treatment and a posttest. The stages of R\&D - ADDIE model can be explained in Table 1 . 
Table 1

Stage of R\&D - ADDIE Model

\begin{tabular}{ll}
\hline Stage & Description \\
\hline Analysis & $\begin{array}{l}\text { The initial needs analysis was done by gathering information and formulating a } \\
\text { general description of the 3D visualization learning media that will be developed } \\
\text { to suit the characteristics of the students. }\end{array}$ \\
The design stages were in the form of product to design 3D visualization media \\
and learning designs that will be applied in the classroom \\
Develop & $\begin{array}{l}\text { The development of 3D visualization products based virtual reality laboratories } \\
\text { was validated by material experts and media experts }\end{array}$ \\
Implement & $\begin{array}{l}\text { The 3D visualization products were implemented to be tested for effectiveness } \\
\text { Evaluate }\end{array}$
\end{tabular}

\section{Participants}

The research was conducted at a public senior high school in Gunungkidul, Yogyakarta, Indonesia. Participants in this study were from grade 10. For the purpose of this study, as many as 96 students (54 female and 42 male) were cluster randomly selected from a public senior high school in those regency. The average age of students was 15 years old. The samples were classified into three different classes, class CG, class EG-1, and class EG-2, each class consist 32 students.

\section{Data Collection}

The variable measured in this study was the student's critical thinking skills and scientific attitude. The data of students' critical thinking skills were collected through chemical bonding test and those of the data students' scientific attitude was collected through questionnaire. Chemical bonding test consists 6 items of short essay and questionnaire consisting of 15 items. The questionnaire was adapted from those found in several books and journal articles on scientific attitude.

The chemical bonding test and scientific attitude questionnaire analysis were done by validity and reliability tests. Those chemical bonding test and scientific attitude questionnaire were validated theoretically and empirically. The theoretical validity was done by asking the expert judgment in terms of material, construction, and language from expert lecturer. The theoretical validity analysis was performed using Aikens' V, formulated as follows (Aiken, 1985).

$$
V=\frac{\sum s}{[n(c-1)]}
$$

Note: $\mathrm{s}=\mathrm{r}-\mathrm{lo} ; \mathrm{r}=$ number of raters; lo $=$ lowest validity score; $\mathrm{c}=$ highest validity score; $r=$ number given by raters.

The calculation result of the Aiken's V value compared with the value of the validity coefficient based on the interpretation guideline of uncorrected correlation coefficients in the predictive validity study (Emery \& Bell, 2009) presented in Table 2. 
Table 2

The Interpretation Guideline of Uncorrected Correlation Coefficients on Predictive Validity Study

\begin{tabular}{ll}
\hline Validity Coefficient & Interpretation \\
\hline$>0.35$ & Very useful \\
$0.21-0.35$ & Useful \\
$0.11-0.20$ & Depend on condition \\
$<0.11$ & Not useful \\
\hline
\end{tabular}

The item used very useful interpretation which has a value of Aiken's V greater than the value of the validity coefficient of 0.35 . The analysis result showed that all chemical bonding test and scientific attitude questionnaire have a validity coefficient $>0.35$. So that, it can be said chemical bonding test and scientific attitude questionnaire were theoretically valid.

Furthermore, empirical validity was done by testing all chemical bonding test and scientific attitude questionnaire against the other students that not used as the samples in this study. A total of 264 students were obtained to test the chemical bonding test and 275 students were obtained to test the scientific attitude questionnaire. The QUEST program was used to conduct the empirical validity and reliability. The items are valid if infit mean square score was in the range of 0.77 to 1.33 and items have good reliability if the score equal to or more than 0.70 . Based on the result of empirical validity analysis there were all items of chemical bonding test was valid, but 1 item of scientific attitude questionnaire not valid. In addition, the analysis results show a reliability estimate chemical bonding test of 0.82 and scientific attitude questionnaire of 0.84 .

\section{Data Analysis}

Multivariate Analysis of Variance (MANOVA) was used for testing the data obtained in the study with all manova test requirements been carried out and the conditions fulfilled. Quality of 3D visualization media was analyzed by quantitative descriptive method. These scores then converted into an interval data scale. Furthermore, the data were classified into a category based on the ideal rating category and can be seen in Table 3 .

Table 3

Ideal Rating Category

\begin{tabular}{ll}
\hline Score & Range Quality \\
\hline $\bar{X}>\bar{X}_{\mathrm{I}}+1.8 \mathrm{SBi}$ & Excellent \\
\hline $\bar{X}_{0}+0.6 \mathrm{SBi}<\bar{X} \leq \bar{X}_{0}+1.8 \mathrm{SBi}$ & Good \\
\hline$\overline{X_{0}}-0.6 \mathrm{SBi}<\bar{X} \leq \bar{X}_{0}+0.6 \mathrm{SBi}$ & Good Enough \\
\hline $\bar{X}_{0}-1.8 \mathrm{SBi}<\bar{X} \leq \bar{X}_{0}-0.6 \mathrm{SBi}$ & Poor \\
\hline $\bar{X} \leq \bar{X}_{1}-1.8 \mathrm{Sbi}$ & Very Poor \\
\hline
\end{tabular}

Note: $X$ is empirical score; $X_{\mathrm{f}}$ is average of ideal scores; $\mathrm{SBi}$ is ideal score of deviation. 


\section{FINDINGS AND DISCUSSION}

\section{Developing Process}

The virtual reality may fail to meet learners' needs if learning activities and tasks are designed inside an inappropriate pedagogical approach (Shih \& Yang, 2008). Instructional designers or educators face the challenge of deploying features of virtual reality into their 3D visualization courses. One of the best-valued features of virtual reality was the ability of providing highly interactive learning experiences. Markerbased virtual reality application has been developed and computer hardware pieces were used as a teaching material. Before starting to develop a 3D visualization application, author researched existing tools and technologies in the field. It was decided on Blender and Unity tool which have good support and documentation. Blender is a program to build 3D object and unity is an ultimate game development platform to build highquality $3 \mathrm{D}$ and 2D games. Key components used in the development process are given in Figure 1.

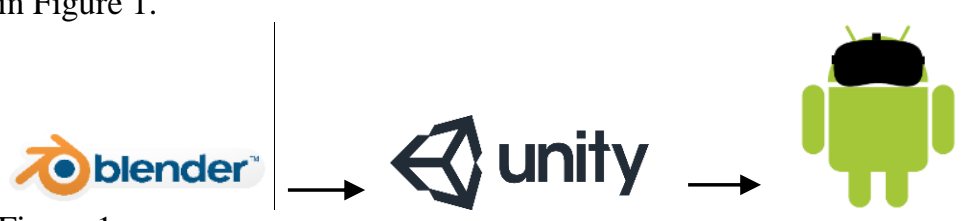

Figure 1

3D Visualization Based Virtual Reality Development Process

The virtual reality product development process using the Blender program that has been incorporated into the Unity program can be seen in Figure 2.

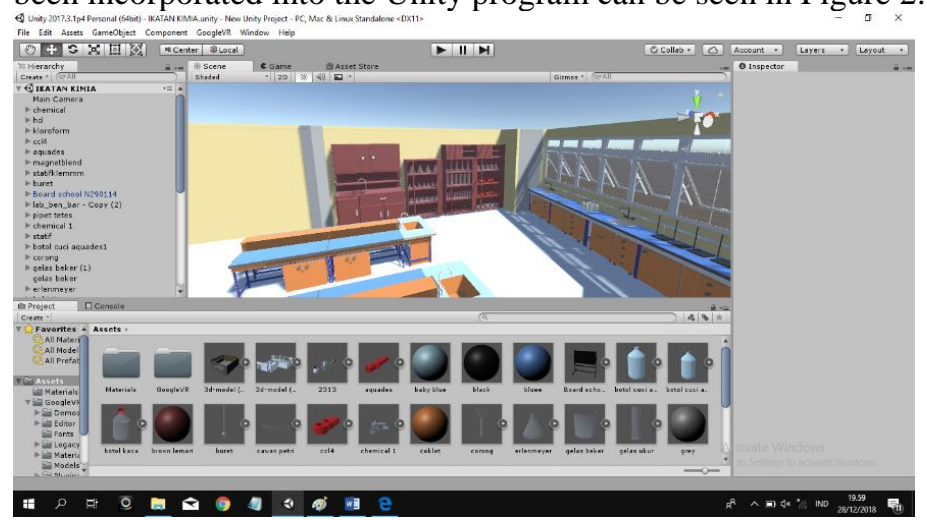

Figure 2

Virtual Reality Layout Design

Virtual reality products can be used using Android and are equipped with 3D glasses (oculus) and controllers. The results of developing 3D visualization final products based virtual reality laboratories can be seen in Figure 3 and the display of virtual reality laboratories with 3D glasses (oculus) can be seen in Figure 4. 


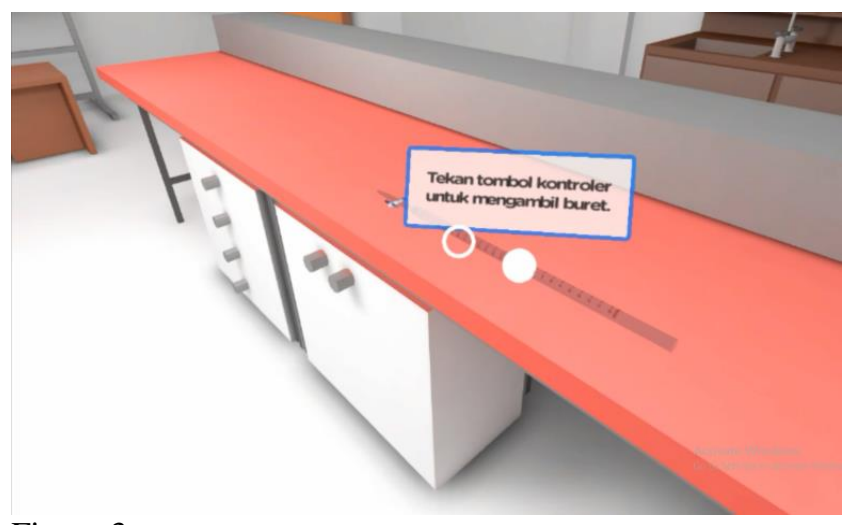

Figure 3

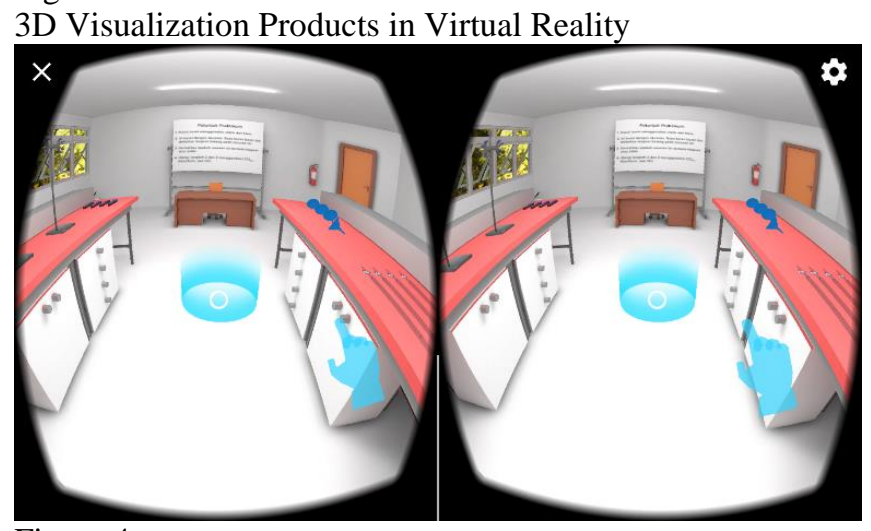

Figure 4

Display of Virtual Reality Laboratory with Oculus

The 3D full immersive virtual reality will elevate a learner's interest and motivation compared with learning in a 2D animated environment (Limniou et al., 2008). Virtual reality (VR) can help students understand learning material in the learning process by observing and making observations. These observations create an impression of depth and imagination in students, so it's easy to remember what has been done using VR.

\section{Effect of 3D visualization on students' critical thinking skills and scientific attitude}

The chemical bonding test and scientific attitude questionnaire used in the study have been empirically validated and theoretically validated by examined by expert judgment. According to expert judgment the chemical bonding test and scientific attitude questionnaire were valid and suitable for use with some revision then empirically validated. The total number of students who completed this chemical bonding test was 264 and 275 students who completed the scientific attitude questionnaire. The QUEST program was used to conduct the empirical validity. The validity of fit item was more than 0.77 and less than 1.30. The empirical validity of chemical bonding test and scientific attitude questionnaire can be seen in Figure 5 and Figure 6. 


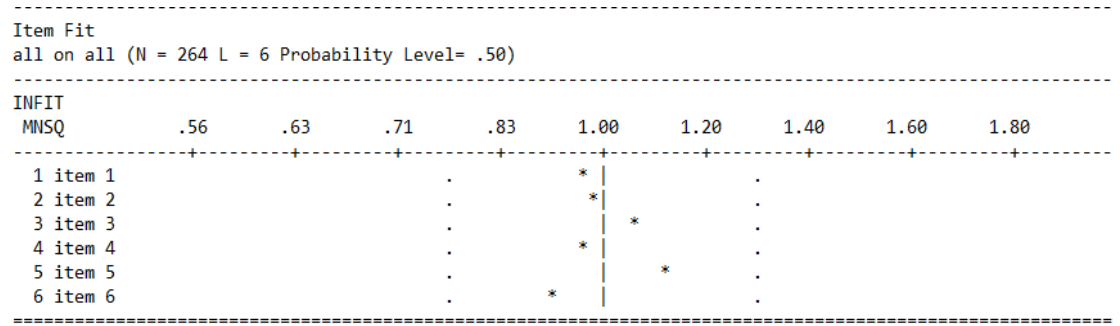

Figure 5

Empirical Validity Results of Chemical Bonding Test

Item Fit

all on all $(\mathrm{N}=275 \mathrm{~L}=15$ Probability Level $=.50)$

\begin{tabular}{|c|c|c|c|c|c|c|c|c|c|c|c|}
\hline \multicolumn{12}{|c|}{ INFIT } \\
\hline MNS & & .56 & .63 & .71 & .83 & & .00 & 1.20 & 1.40 & 1.60 & 1.80 \\
\hline & item 1 & & & & & & |* & & . & & \\
\hline & item 2 & & & & & & i & & & & \\
\hline & item 3 & & & & & & |* & & . & & \\
\hline & item 4 & & & & & * & *1 & & & & \\
\hline & item 5 & & & & & & i & & & & \\
\hline 6 & item 6 & & & & & * & *i & & & & \\
\hline & item 7 & & & & & & i & & . & & \\
\hline & item 8 & & & & & & $*$ & & . & & \\
\hline 9 & item 9 & & & & & & I & & & & \\
\hline 10 & item 10 & & & & & & i & * & & & \\
\hline 11 & item 11 & & & & & & i & & & & \\
\hline 12 & item 12 & & & & & & & & & & \\
\hline 13 & item 13 & & & * & & & & & & & \\
\hline 14 & item 14 & & & & & * & & & & & \\
\hline 15 & item 15 & & & & & & i* & & & & \\
\hline
\end{tabular}

Figure 6

Empirical Validity Results of Scientific Attitude Questionnaire

Based on Figure 5 and Figure 6, all the chemical bonding test was valid, but in the scientific attitude questionnaire, among 15 items, there were 1 item that the expert considered unfit for inclusion. Because item number 13 was not valid, only 14 items of scientific attitude questionnaire were used.

The QUEST program also used to conduct the reliability test. The interpretation of reliability score of chemical bonding test and scientific attitude questionnaire can be seen in Figure 7.

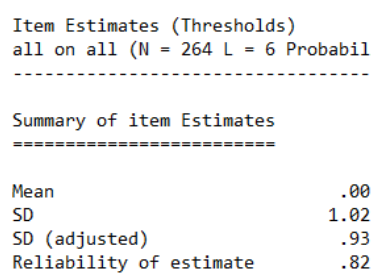

Chemical Bonding Test

Figure 7

Reliability Results of Empirical Tests
Item Estimates (Thresholds) all on all $(\mathrm{N}=275 \mathrm{~L}=15$ Probability Level $=.50)$

Summary of item Estimates

$\begin{array}{ll}\text { Mean } & .00 \\ \text { SD } & .85 \\ \text { SD (adjusted) } & .78 \\ \text { Reliability of estimate } & .84\end{array}$

(b) Scientific Attitude Questionnaire 
The reliability of the chemical bonding test proved adequate $(\alpha=0.82)$ and scientific attitude questionnaire proved adequate $(\alpha=0.84)$. This reliability states that both of them have been reliable to use.

The 3D visualization media based virtual reality was implemented in 3 classes namely control group (CG) and experiment group (EG-1 and EG-2). Class CG conducts learning using wet laboratory, class EG-1 implements learning using a virtual reality laboratory integrated hybrid learning and class EG-2 carrying out learning using wet laboratory and virtual reality-based hybrid learning. From the results of the trials obtained the average value of critical thinking skills and scientific attitudes of the three classes. The comparison of students' critical thinking skills and scientific attitude in each class can be seen in Figure 8.

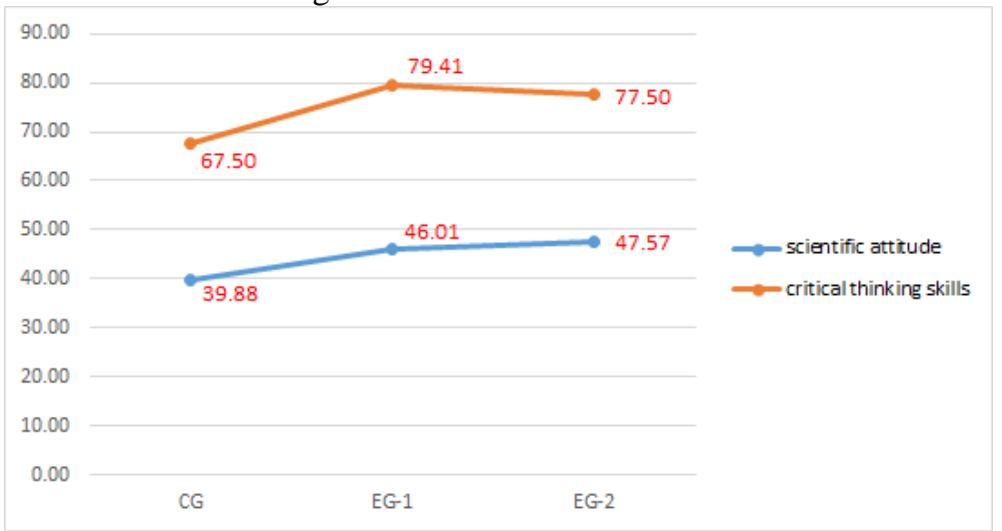

Figure 8

The Comparison of Students' Critical Thinking Skills and Scientific Attitude

Based on Figure 8, every class used in this study shows the results that students' critical thinking skills and scientific attitude for class EG-1 and class EG-2 higher than class CG. This was because in the class EG-1 and class EG-2 used virtual reality that can facilitate students to learn independently. The 3D visualization based virtual reality can be used as an independent learning sources and very flexible in the chemical bonding teaching-learning because it can be used anywhere and anytime.

The students' critical thinking skills and scientific attitude were analysed by MANOVA. Before carrying out the MANOVA analysis a prerequisite test was conducted in the form of a multivariate normality and covariance homogeneity test. The multivariate normality test was done by comparing the distance of the Mahalonobis $\left(d_{f}^{2}\right)$ with the value of chi square $(x)^{2}$ for each group. Data was multivariate normally distributed if the scatter-plot graph tends to form a straight line or more than $50 \%$ the distance value of mahalanobis $\left(d_{i}^{2}\right)$ is less or equal to the value of chi square $(x)^{2}$. The graph of the results of the multivariate normality test can be seen in Figure 9. 


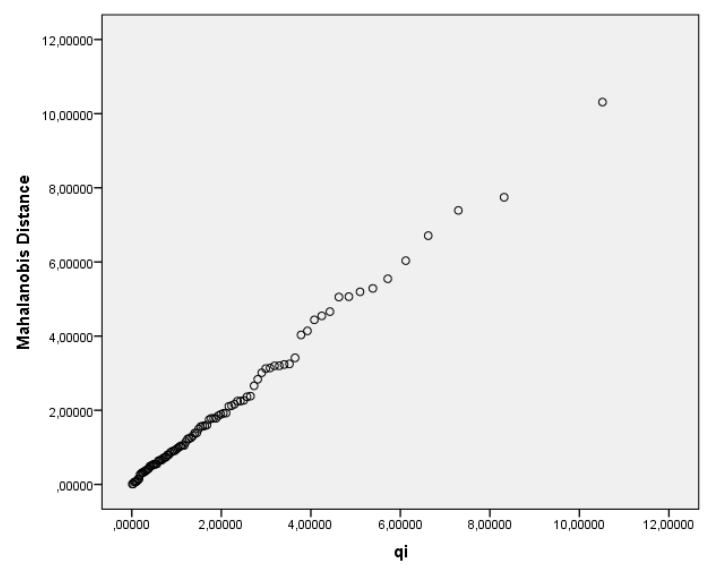

Figure 9

Graph of Multivariate Normality Test

Based on Figure 9 it can be seen that the graph tends to form a straight line. This indicates that students' data of critical thinking and scientific attitude results of product testing were normally distributed.

Covariance matrix homogeneity test can be seen based on Box's M. Data comes from populations that have a homogeneous covariance matrix if the significance value was more than 0.05 . The result of the homogeneity test can be seen in Table 4 .

Table 4

Result of Homogeneity Test

\begin{tabular}{lllllll}
\hline Variable & & Box's M & F & df1 & df2 & Sig \\
\hline $\begin{array}{l}\text { Critical Thinking Skills and } \\
\text { Scientific Attitude }\end{array}$ & 9.702 & 1.567 & 6 & 215559.692 & 0.152 \\
\hline
\end{tabular}

Based on Box's M test results, the significance results are 0.152, this indicates that the three classes have the same covariance matrix.

MANOVA analysis based on Wilks' Lambda was used in this study because the sample consisted of more than two independent groups (Muijs, 2011) and manova assumptions were met (Hair et al., 2006). The results of MANOVA analysis can be seen in Table 5.

Table 5

Result of Wilks' Lambda Multivariate Test

\begin{tabular}{lll}
\hline Effect & Significance & Decision Criteria \\
\hline Wilks' Lambda & 0.000 & Sig. $<0.05$ \\
\hline
\end{tabular}

As Table 5 shows, the sig. score was 0.000 , less than $\alpha=0.05$. It can be concluded that at the $95 \%$ confident level there is a significant influence of the treatment on students' critical thinking skills and scientific attitude. The presence of significant influence caused by different treatment in each class. This study confirms the 3D visualization has a positive effect on students' performance in hybrid learning. On the other hand, interactive learning by using simulations based virtual reality laboratory, where students 
become active in their learning, provide opportunities for students to construct and understand difficult concepts more easily (Demirci, 2003) and generally increase learning speed by allowing students to express their real reactions easily (Bajpai \& Kumar, 2015). The 3D visualization helps to improve a student's imagination by developing a student's capacity to detect and follow near invisible cues. Barab et al. (2000) found that 3D virtual worlds are an effective tool to foster undergraduate students' understanding of course contents. Students can repeat virtual reality simulations at home or anywhere according to their need so that they will form students' critical thinking skills and scientific attitude.

The evaluation phase in this study was carried out by evaluating the quality of $3 \mathrm{D}$ visualization media in virtual reality. This assessment was carried out by 8 teachers of senior high school using media assessment instruments that have been validated by expert judgment. Assessment was divided into 3 main aspects, namely aspects of learning, material, and technique. Assessments from the teacher are then searched for averages and adjusted to the ideal rating category. The evaluation of the quality of 3D visualization media can be seen in Table 6 .

Table 6

Results of Quality Evaluation of 3D Visualization Media

\begin{tabular}{|c|c|c|}
\hline Aspect & Assessment Result & Category \\
\hline \multicolumn{3}{|l|}{ Learning } \\
\hline Suitability of the media with the student needs & 3.875 & excellent \\
\hline Media supports the process of achieving learning goals & 3.750 & excellent \\
\hline Learning support media using hybrid learning communication models & 3.875 & excellent \\
\hline Media motivates and attracts the attention of students & 3.625 & Excellent \\
\hline Media helps the learning process & 3.750 & excellent \\
\hline Visual media design matches the user & 3.875 & excellent \\
\hline Media can stimulate students to do practicum & 3.500 & excellent \\
\hline Media facilitates students to acquire new skills & 3.750 & excellent \\
\hline $\begin{array}{l}\text { Simulation of practical activities provides interactive learning } \\
\text { opportunities }\end{array}$ & 3.500 & excellent \\
\hline \multicolumn{3}{|l|}{ Material } \\
\hline The concept of practicing chemical bonding is correct & 3.375 & excellent \\
\hline Media content is accurate & 3.875 & excellent \\
\hline Content in the media contains educational value & 3.750 & excellent \\
\hline The content presented is easily understood by students & 3.750 & excellent \\
\hline $\begin{array}{l}\text { Content in the media is interrelated to clarify the delivery of } \\
\text { information }\end{array}$ & 3.750 & excellent \\
\hline \multicolumn{3}{|l|}{ Technique } \\
\hline Use of proportional layouts & 3.875 & excellent \\
\hline Display colors and background & 3.625 & excellent \\
\hline The relevance of media to technology that is developing at this time & 3.750 & excellent \\
\hline Ease of navigation & 3.750 & excellent \\
\hline Accuracy of visualization & 3.875 & excellent \\
\hline Suitability of 3D objects & 3.875 & excellent \\
\hline Clarity of illustration & 3.625 & excellent \\
\hline Media creativity and innovation & 3.750 & excellent \\
\hline Average & 3.733 & \\
\hline
\end{tabular}

The average assessment score for quality of $3 \mathrm{D}$ visualization was 3.733 in the "excellent" category. From these results it can be concluded that 3D visualization media 
was suitable to be used in the learning process effectively and efficiently. This media can improve students' critical thinking skills and scientific attitude well. Learning media such as 3D visualization have a positive influence in gaining learning experience, getting used to doing scientific attitudes, exercising imagination, increasing critical thinking skills, and improving learning outcomes (Barab et al., 2000; Higgins et al., 2014; Jabbour, 2014; Omilani et al., 2016).

The advantages of 3D visualization media include: this media can be used anytime and anywhere, helping users to visualize 3D objects, can avoid accidents in real laboratories, and users can interact directly with objects in virtual reality laboratory media. The disadvantage of 3D visualization media is this media can only be operated using a smartphone, while the computer can only display the simulation with the control of the smartphone. This is because the use of this media requires supporting devices, 3D glasses (oculus) and a controller.

\section{CONCLUSION}

The developed product of 3D visualization based on virtual reality showed that: (1) the $3 \mathrm{D}$ visualization media can be operated in Android with the help of 3D glasses (oculus) and controller, (2) students can use 3D visualization media both in the classroom and outside the classroom, (3) 3D visualization media effectively improved students' critical thinking skills and scientific attitude, and (4) the quality of 3D visualization media was "excellent" category. Suggestions for the use of 3D visualization products based on the results of research and development is that the virtual reality media can be further developed with different chapter. In addition, this media can be used as classroom action research by chemistry teachers with other variable.

\section{ACKNOWLEDGEMENT}

Authors would like to thank to Directorate General of Higher Education, Ministry of Research, Technology and Higher Education, Indonesia for funding of this research with the contract No. 10/PenelitianTimPascasarjana/UN34.21/2018.

The authors declare that there is no conflict of interest.

\section{REFERENCES}

Aiken, L. R. (1985). Three coefficients for analyzing the reliability and validity of ratings. Edu.\&Psyc. Meas., 45(1), 131-142. https://doi.org/10.1177/0013164485451012.

Antonoglou, L. D., Charistos, N. D., \& Sigalas, M. P. (2011). Design, development and implementation of a technology enhanced hybrid course on molecular symmetry: Students' outcomes and attitudes. Chem. Educ. Res. Pract., 12(4), 454-468. https://doi.org/10.1039/C0RP90013C.

Allwright, D. (1991). Autonomy and individualization in whole-class instruction. London: Modern English Publications \& The British Council.

Astutik, S., \& Prahani, B. K. (2018). The practicality and effectiveness of collaborative creativity learning (CCL) model by using PhET simulation to increase sudents' scientific creativity. Int.J. Ins, 11(4), 409-424. https://doi.org/10.12973/iji.2018.11426a. 
Bajpai, M., \& Kumar, A. (2015). Effect of virtual laboratory on students' conceptual achievement in physics. International Journal of Current Research, 7(2), 12808-12813.

Bakar, N., Zaman, H. B., Kamalrudin, M., Jusoff, K., \& Khamis. N. (2013). An effective virtual laboratory approach for chemistry. A. J. of Bas \& App. Sci, 7(3), 78-84.

Barab, S. A., Hay, K. E., Squire, K., Barnett, M., Schmidt, R., \& Karrigan, K., Yamagata-Lynch, L., \& Johnson, C. (2000). Virtual solar system project: learning through a technology-rich, inquiry-based, participatory learning environment. J. of Sci. Education and Technology, 9(1), 7-25. https://doi.org/10.1023/A:1009416822783.

Bart, W. M. (2010). The measurement and teaching of critical thinking skills. Invited, colloquium given at the Center for Research on Education Testing, Tokyo, Japan.

Daud, N. M., \& Husin, Z. (2004). Developing critical thinking skills in computer-aided extended reading classes. British Journal of Educational Technology, 35(4), 477-487. https://doi.org/10.1111/j.0007-1013.2004.00405.x.

Emery, J. L., \& Bell, J. F. (2009). The predictive validity of the biomedical admissions test for pre-clinical examination performance. Medical Education, 43(6), 557-564. https://doi.org/10.1111/j.1365-2923.2009.03367.x.

Ennis, R. H. (1993). Critical thinking assessment. Theory into Practice, 32(3), 179-186. https://doi.org/10.1080/00405849309543594.

Ennis, R. H. (2009). An annotated list of critical thinking tests. Retrieved from http://www.criticalthinking.net/TestListRevised11-27-09.pdf

Hair, J. F., Anderson, R. E., Tatham, R. L., \& Black, W. C. (2006). Multivariate data analysis. New Jersey: Prentice-Hall International, Inc.

Hawkins, I., \& Phelps, A. J. (2013). Virtual laboratory vs. traditional laboratory: Which is more effective for teaching electrochemistry? Chemistry Education Research and Practice, 14(4), 516-523. https://doi.org/10.1039/c3rp00070b.

Higgins, S., Xiao, Z., \& Katsipataki, M. (2012). The impact of digital technology on learning: A summary for the education endowment foundation. Durham: Durham University.

Jabbour, K. K. (2014). An analysis of the effect of mobile learning on Lebanese higher education. Informatics in Education, 13(1), 1-15.

Jancirani, R., Dhevakhrisnan, R., \& Devi, S. (2012). A study on scientific attitude of adolescene students in namakkal district. Int. Educational E-Journal, 1(4), 2-8.

Lewis, A., \& Smith, D. (1993). Defining higher order thinking. Theory into Practice, 32(3), 131-137. https://doi.org/10.1080/00405849309543588.

Limniou, M., Roberts, D., \& Papadopoulos, N. (2008). Full immersive virtual environment CAVETM in chemistry education. Computer \& Education, 51(2), 584593. https://doi.org/10.1016/j.compedu.2007.06.014.

Muijs, D. (2011). Doing quantitative research in education with SPSS. London: SAGE.

Olasehinde, K. J., \& Olatoye, R. A. (2014). Scientific attitude, attitude to science and science achievement of secondary school student in Katsina State, Nigeria. J. of Edu. and Social Research, 4(1), 445-452. https://doi.org/10.5901/jesr.2014.v4n1p445. 
Omilani, N. A., Ochanya, N. M. R., \& Aminu, S. A. (2016), The effect of combined virtual and real laboratories on students' achievement in practical chemistry. Int. J. of Secondary Education, 4(3), 27-31. https://doi.org/10.11648/j.ijsedu.20160403.11.

Pitafi, A.I., \& Farooq, M. (2012). Measurement of scientific attitude of secondary school student in Pakistan. Academic Research International, 2(2), 379-392.

Paul, R., \& Elder, L. (2006). The miniature guide to critical thinking concepts and tool. Retrieved from http://www.criticalthinking.org/files/Concepts_Tools.pdf

Perkins, C., \& Murphy E. (2006). Identifying and measuring individual engagement in critical thinking in online discussions: An exploratory study. Educational Technology \& Society, 9(1), 298-307.

Roekel, D. V (2012). Preparing $21^{\text {st }}$ century students for a global society: an educator guide to the "four cs". USA: National Education Association.

Rutten, N., van Joolingen, W. R., \& van der Veen, J. T. (2012). The learning effects of computer simulations in science education. Computers \& Education, 58(1), 136-153. https://doi.org/10.1016/j.compedu.2011.07.017.

Saavedra, A. R., \& Opfer, V. D. (2012). Teaching and Learning 21 st century Skill: Lessons from the learning sciences. Paper presented at the Joint AARE/APERA Conference, Sydney. Retrieved from http://asiasociety.org/files/rand-1012report.pdf.

Senler, B. (2016). Pre-service teachers' self-efficacy: The role of attitude, anxiety and locus of control. Australian Council for Educational Research, 60(1), 26-41. https://doi.org/10.1177/0004944116629807.

Shih, Y. C., \& Yang, M. T. (2008). A collaborative virtual environment for situated language learning using VEC3D. Educational Technology \& Society, 11(1), 56-68.

Solikhin, F., Sugiyarto, K. H., \& Ikhsan, J. (2018). The measurement of self-efficacy in the use of VICH-LAB in electrochemistry. AIP Conference Proceedings 2021, 040002 (2018). https://doi.org/10.1063/1.5062746.

Sural, I. (2018). Augmented reality experience: Initial perceptions of higher education students. Int. J. of Instruction, 11(4), 565-576. https://doi.org/10.12973/iji.2018.11435a.

Wagner, T. (2008). The global achievement gap: Why even our best schools don't teach the new survival skills our children need and what we can do about it. New York, NY: Basic Books.

Wu, H., He, Z., \& Gong, J. (2010). A virtual globe-based 3D visualization and interactive framework for public participation in urban planning processes. Computers, Env.\& Urb. Sys., 34(4), 291-298. https://doi.org/10.1016/j.compenvurbsys.2009.12.001.

Zhao, Y., \& Breslow, L. (2013). Literature review on hybrid/blended learning. Massachusetts Institute of Technology, Teaching and Learning Laboratory Working Paper. Retrieved from http://tll.mit.edu/sites/default/files/library/Blended_Learning_Lit_Review.pdf. 